\title{
Review Paper on the Study of Perforated Concrete Pavement
}

\author{
Shashank Moon ${ }^{1}$, Nikita Tembhurne ${ }^{2}$, Boaz Barve ${ }^{3}$, Aman Rangari ${ }^{4}$, Pooja Bansond ${ }^{5}$, Prof. Abdul Gaffar ${ }^{6}$ \\ ${ }^{12345}$ B tech students, Civil Department, DBATU University, lonere, Maharashtra, India \\ Professor and HOD Abdul Gaffar 6 , Department of Civil Engineering, Nagpur, Maharashtra, India
}

JDCOEM

\begin{abstract}
Permeable pavement typically consist of pervious concrete, porous asphalt, permeable interlocking concrete paving units or grid type system over an open graded/sub base layer (s), permeable pavement infiltrate storm water, reduce peak flow, filter and clean contaminant and promote groundwater recharge. They have gained substantial popularity in North America and have become an integral part of low impact design and best management practices for storm water management. In order to be effective, permeable pavement must be design to provide sufficient structural capacity to accommodate the anticipated vehicle loading, manage storm water flow into the surface and soil sub grade, as well water draining out of the base/sub base. While there are many well-designed and constructed permeable pavement, they are a relatively new technology with some projects performing below design expectation, this paper describe some essential best practices for permeable pave design and construction, and focuses on lesson learned from case studies of permeable pavement construction in North America.
\end{abstract}

Keyword - Perforated concrete, Storm Water, run off management, rural area, urban area

\section{I) INTRODUCTION:}

Pervious cement is blend of rock, concrete, water, practically zero sand (fine total) with or without admixtures. At the point when pervious concrete is utilized for clearing the open cell structures permits the storm water to channel through the asphalt and into the basic soils. We can likewise say that pervious solid aides in securing the outside of the asphalt and its condition. Pervious asphalt go about as both an asphalt and tempest water the board device. The total is for the most part of a solitary size and is limited mutually in a concrete glue. Utilizing adequate glue to cover and tie the total particles together makes high porous framework with interconnected voids which depletes rapidly. We can be likewise given a punctured channel to gather it and channels to the required treatment plant.

Pervious concrete can be used for a number of application, but it is primary use in road pavement such as rural areas, this report will focus on the pavement application of the concrete, which also has been referred to as porous concrete, permeable concrete, no fines concrete, porosity concrete. pervious concrete is zero slump open graded material consisting of cement coarse aggregate of cement, coarse aggregate admixture and water, pervious concrete contain little or no fines aggregate such as sand it is sometimes use as 'non fines' concrete. Pervious concrete are designed to achieve water quality and quantity benefits by allowing movement of Storm water through the pavement surface and into a base/subbase reservoir. The water passes through the voids in the pavement material and provides the structural support conventional pavement, that's why pervious pavement can be served as an alternative to conventional road and parking lots this pavement have ability to reduce urban runoff and trap pollution. Also it provides opportunities to reduce the impact of urbanization on the management of Storm water.

\section{II)LITERATURE REVIEW SURVEY}

1.Mr. Gaurav UttamShinde \& Dr. S. S. Valunjkar in 2015, in this paper intentional on Cost and Time Control in Storm Water Management using Pervious Concrete. They study the pervious concrete in metro cities \& the previous concrete has introduced in metro cities as a road pavement material. They said that, in metro city pavement pervious concrete is new concept because of problems in urban area related to low ground water table \& storm water management. In this paper one case study is analysed. Considering rainfall data, traffic volume data, soil \& geotechnical investigation data of a residential colony which was taken as a part of a case study, the suitability of a previous concrete was checked. Cost comparison between conventional method of storm water management and storm water management using previous concrete pavement is checked. This paper states that, in metro cities cost consideration is the primary factor. Maintenance of costly storm water management system is difficult to execute in cities due to its large population. They also states that, previous concrete pavement is irreplaceable and effective means to meet growing environment and population demand.

2.Jannathul Thasni. P, JouharShareef, (2018), in this paper has summarize research on water absorbing pavement by the porous concrete, they discuss about the solution for low ground water level, agriculture problem, management of storm water runoff. Application and engineering property of porous concrete are discussed, they also studied about material of porous pavement such as cement, aggregates, water, admixture and etc. Benefit, advantage and disadvantage, durability, strength of porous concrete are also highlighted. In this paper they discourse about replacement of cement by fly ash which result is safe disposal safe material in porous concrete hence its acts eco-friendly paving pavement. 
3.Jayeshkumar Pitroda \& J. J. Bhavsar in 2013, they have studied that on rural area. They said that, perforated concrete is a relatively new concept for Rural Road Pavement. With increase into the ground water level, agriculture problems. The previous concrete is used as paving material.They states that, In the rural area, Cost consideration is very important factor which must be kept in mind. So that in rural areas Costly storm water management practices is not applicable. They conclude that is to capture the rainwater \& allowing it to seep into the ground. This pavement technology creates more efficient land use by eliminating the need for relation ponds, swell \& other costly storm water management devices.

4.Mosoud Kayhanin, Hui Li, \& John T. Harvey in 2019, they considered that on the perforated pavement in Highways for storm water runoff management and pollution prevention. They have discuss \& summarize the major findings of these collective studies related to, Hydraulic performance evaluation of permeable pavement, Permeability measurement of porous asphalt and previous concrete paved surfaces, Clogging evaluation of permeable pavement surfaces, and Water quality and pollution control issues. They said that In the future, permeable pavements including the Full Depth Permeable Pavement (FDPP) will be part of an integrated sustainable transportation program. They states that, if FDPP designed property, it can be used as an alternative best management practice (BMP) for storm water runoff management. They states that the specific characteristics of FDPP throughout the life of pavements. Surface pavement remain highly permeable and unclogged, Allowing minimum permeability of subgrade soil to infiltrate the captured runoff, assuming no adverse impact on underground water.

5.Saurabh Y. Kale, Amit P. Halwele ${ }^{2}$, Kartik Rathod ${ }^{3}$, Mayur A. Jirapure In 2017, they perform the research on Permeable pavement system and their uses. In this paper, they studied about Permeable pavement system, sustainable drainage system, porous pavement, storm water, sustainability, filtration, drain, geothermal heating and cooling. Water quality control and maintainace are highlighted, deliberated about recent innovation, advantage and disadvantages in this paper. They concentrated on the use of permeable pavement in sustainable urban drainage system. The moto of this paper is to show the application of permeable pavement in drainage system.

6.Vikram1, Mehla R. P. in 2015, In this paper, Different blend extents were set up by supplanting concrete with silica rage (6\%) and expansion of super plasticizers (0.13-0.25\%) with fluctuating size of total (4.75-20) have been utilized for examining properties of new and solidify pervious cement. W/C proportion kept steady 0.34 . various properties of pervious cement e.g., functionality, compressive quality, split rigidity, flexural quality t 7,28,56 days and bond quality at 28 and 56 days have been concentrated tentatively. Results indicated that quality of pervious cement is diminished with expansion of Silica flume and super plastizers. The blend extent in with total size $(4.75-10 \mathrm{~mm})$ invigorates better contrasted with $(10-20 \mathrm{~mm})$ and $(4.75-20$ $\mathrm{mm})$.

7.A.M. Admire, A. V. Gandhi, S. S. Adsul, A. A. Agarkar, G. S. Bhor, G.P. Kolte, has summarize literature on permeable pavements. Also describe about the permissible pavement, their types in which pervious concrete is most common today. They had also describe about the needs and applications of previous pavement, their life span that how long it's life will be, the water quality which pass through pavement. They have also discussed about the future scope and research.

8.Javier Castro (Graduate Research Assistant), in 2010, in this paper states an experimental study on transport proprieties of concrete are controlled by the characteristics of its pore network. Total porosity, pore size, pore connectivity, and pore saturation all influence the measured transport coefficients (Garboczi 1990; Bentz et al. 1999) Considerable research has been based on environmentally sustainable development. This has mainly to the use of pervious concrete in place of conventional concrete. Pervious concrete has been used as an effective method for handling and reducing negative environmental impacts. The voids are creates in the concrete for passing the water from concrete, also reducing the problem of water logging and make a road surface skid resistance and increasing the water table, The performance of pervious concrete was compared with the material used for the construction of concrete road pavements. The tests were conducted to determine the properties of concrete like compression strength, flexural strength and also permeability of concrete. It was found that pervious concrete pavements possesses some positive features like increased skid resistance and high permeability but most importantly it requires the high strength for highly trafficked areas. Pervious concrete has proven to have properties suitable for use in low volume traffic areas. If pervious concrete pavements can be implemented, it will have various positive effects on the environment.

9.Dr. M. Mageswari, M. P. Karthikeyan, S. Pavitran, M. Rajkumar \& R. Govindrajan (2016), stated areas follow: Purpose: collects the water stored in concrete and drain sit to the required Treatment plant or a recharge pit. Design: Different combinations of Cement, GGBS, Water and Course aggregate with different maximum size and gradation were adopted for trial mixes to arrive at M20 grade concrete. M20 grade concrete is achieved with a w/c ratio of 0.36 , Coarse aggregate of nominal size $20 \mathrm{~mm}$ passed and $10 \mathrm{~mm}$ retained cement is partly replaced with $30 \%$ of GGBS and With a cement to Course aggregate ratio of 1:4. Its Compressive strength were observed to be $20.4 \mathrm{kN} / \mathrm{m} 3$. A perforated pipe can be provided at centre of the pavement above sub-base.

10.Mohammed Sonebia, Mohamed Bassuonib, Ammar Yahiacin 2016 states that, in this paper for many years, Portland cement pervious concrete (PCPC) has Been making an important contribution, as a sustainable urban drainage 
system (SUDS), in particular. On improving environmental conditions. This type of porous Concrete can help minimizing flooding risks, recharging groundwater table, reducing runoff and peak flows, and improving water quality. In addition, PCPC can be reduce the absorption of solar radiation power and urban heat storage Potential which can lead to temperate urban conditions, in which protecting the environment and health and safety of living things. This increase of impervious surface areas, which block the Percolation of precipitation from rainfall and snow down through the ground. This increases the potential for excess Surface run off, which can lead to downstream flooding, bank and control the pollution.

\section{III)MATERIAL :}

\section{$>$ Cement:}

Evaluation OPC gives high quality and sturdiness to structure in light of its ideal molecule size conveyance and prevalent crystalized structure. Being a high quality concrete, it gives various preferences any place cement to unique high quality application is required, for example, in the development of high rises, spans, flyovers, fireplaces, runways, solid streets and other overwhelming burden bearing structures.

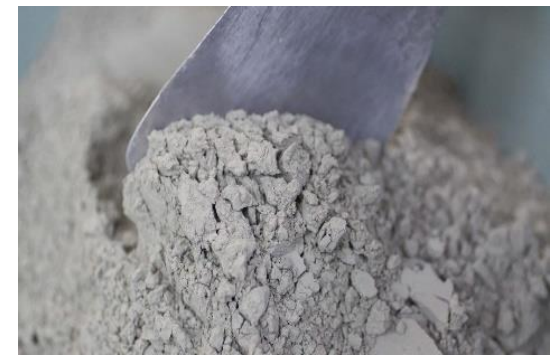

$>$ Coarse Aggregate:

Coarse total was utilized as an essential fixing in making the penetrable cement. Bigger totals give a more unpleasant surface. Ongoing utilizations for pervious cement have concentrated on parking garages, low-traffic asphalts, and walker walkways. For these applications, the littlest estimated total attainable is utilized for stylish reasons. Coarse Totals are those that are held on the sifter of work size $4.75 \mathrm{~mm}$. Their upper size is by and large around $7.5 \mathrm{~mm}$. Rock from waterway bed are the best coarse totals really taking shape of Regular Cement.

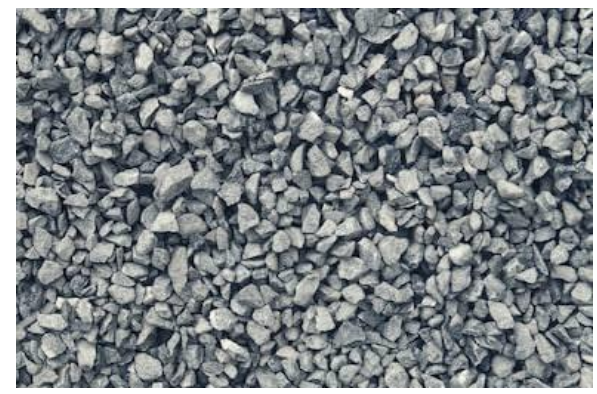

$>$ Water:

Water to cementitious materials proportions between 0.34 and 0.40 are utilized routinely with appropriate incorporation of compound admixtures, and those as high as 0.45 and 0.52 have been utilized effectively. The connection among quality and water to cementitious materials proportion isn't clear for pervious cement on the grounds that not at all like ordinary cement, the all-out glue content is not exactly the voids content between the totals.

\section{$>$ Admixtures:}

Compound admixtures are utilized in pervious cement to acquire unique properties, as in regular cement. Due to the quick setting time related with pervious solid, retarders or hydration-settling admixtures are utilized normally. Here we utilized two distinct admixtures, for example, fly debris and conplastsp 500. Fly debris the consuming of harder, more established anthracite and bituminous coal ordinarily creates Class F fly debris. This fly debris is pozzolonic in nature, and contains under $20 \%$ lime $(\mathrm{CaO})$. It is a fine powder which is result from consuming pounded coal in electric age power plants and it is a pozzolan, a substance containing aluminous and silicious materials that structures concrete within the sight of water. Class F fly debris, withparticles shrouded in a sort of liquefied glass, enormously diminishes the danger of extension because of sulfate assault as may happen in treated soils or close to waterfront areas. Conplast SP500 Conplast SP500 consents to IS: 9103:199 and BS: 5075 Section 3.Conplast SP500 fits in with ASTM-C 494 Sort 'G. It is the elite water lessening andsuper plasticizing admixture. Conplast SP500 depends on Sulphonated Naphthalene Polymers and is provided as an earthy colored fluid in a split second dispersible in water. Conplast SP500 has been uniquely detailed to give high water decreases upto $25 \%$ without loss of usefulness or to create excellent cement. The fundamental preferences of this admixture are improved functionality, expanded quality, improved quality, higher attachment and chloride free.

\section{IV)REFERENCE}

[1] Mr. Gautav Uttam Shinde \& Dr. S. S. Valunjkar, "Cost and Time Control in Storm Water Management using Pervious Concrete". (IJSRD) - International Journal for Scientific Research \& Development - Vol. 3, Issue 02, 2015 - ISSN (online):23210613.

[2] Jannathul Thasni P, Jouhar Shareef, (May 2018), "Water Absorbing Pavements by using Porous Concrete", International Research Journal of Engineering and Technology (IRJET) Volume 5 Issues 5.

[3] Darshan S. Shah, Prof. Jayeshkumar Pitroda, Prof. J. J. Bhavsar, "Pervious Concrete: New Era for Rural Road Pavement". International Journal of Engineering Trends and Technology (IJETT)- Vol.4 Issue 8- August 2013.

[4] Masoud Kayhanian, Hui Li, John T. Harvey, Xiao Liang, "Applications of Permeable Pavements in Highways for stormwater runoff management and pollution prevention". International Journal of Transportation Science and Technology 8 (2019) 358-372. 
[5] Saurabh Y. Kale1, Amit P. Halwele 2 , Kartik Rathod ${ }^{3}$, Mayur A. Jirapure, ( January 2017), "Permeable Pavement a step towards Sustainable Urban Drainage System" International Advanced Research Journal in Science, Engineering and Technology (IARJSET) - Volume 4 Issues 3.

[6] Vikram1, Mehla R. P.2 International Journal for Research in Applied Science and Engineering Technology (2015) (IJRASET).

[7] A.M. Admire, A. V. Gandhi, S. S. Adsul, A. A. Agarkar, G. S. Bhor, G.P. Kolte, (2017), "Permeable Pavement new technology for Construction of Road in India" International Research Journal of Engineering and Technology" (IRJET) - Volume 4 Issues 4.

[8] HandeSagar S.1, Wavhal Rahul K.2, Pawar Sachin A.3, Gaikwad Mahesh J.4 \& Phatangare Roshani. "Water permeable road pavements", International Journal of Engineering Sciences \& Management [Hande, 7(1): January-March 2017] ISSN 2277 -5528 .

[9] Dr. M. Mageswari, M. P. Karthikeyan, S. Pavitran, M. Rajkumar \& Govindrajan, "High Strength Permeable Pavement using No Fines Concrete ". SSRG International Journal of Civil Engineering (SSRG-IJCE)-Vol.3Issues 3-March2016.

[10] Mohammed Sonebia, Mohamed Bassuonib, Ammar Yahiac. "Pervious Concrete: Mix Design, Properties and Applications". RILEM technical letters 2016. 